\title{
CORROSION BEHAVIOUR OF AISI 460LI SUPER-FERRITIC STAINLESS STEEL
}

\author{
Andrea Di Schino ${ }^{I)^{*}}$ \\ 1) Università degli Studi di Perugia, Dipartimento di Ingegneria, Perugia, Italy
}

Received: 21.10.2019

Accepted: 31.10.2019

${ }^{*}$ Corresponding author: andrea.dischino@unipg.it, Dipartimento di Ingegneria, Università di Perugia, Via G. Duranti, 01625 Perugia, Italy

\begin{abstract}
Following nickel and molybdenum significant price increase, nowadays the stainless steel market is moving toward an increasing use of ferritic stainless steel instead of austenitic stainless and therefore to the development of advanced ferritic stainless steels grades aimed to substitute the more expensive austenitic materials in all applications allowing it. Super-ferritic stainless steels are higher chromium $(\mathrm{Cr})$ and molybdenum (Mo) steels with properties similar to those of standard ferritic alloys. Such elements increase high temperature and corrosion resistance in strong environment. This paper deal about the corrosion resistance of super-ferritic stainless steels with a $\mathrm{Cr}$ content ranging from $21 \%$ to $24 \%$.
\end{abstract}

Keywords: Stainless steels, corrosion resistance, microstructure

\section{Introduction}

Stainless steels are nowadays applied in many applications facing with strength/ductility requirements coupled with corrosion resistance high targets. In particular, they are adopted in automotive [1-7], construction and building [8-9], energy [10-13], aeronautical [14], medical [15], food [16-21] and 3D printing [22-26] applications. Ferritic stainless steels are more and more required following their lower cost with respect to austenitic stainless steels. As a consequence, there is a strong market demand for innovative ferritic stainless steel grades with the aim to substitute the most expensive austenitic grades in all those applications allowing it.

Based on the above considerations, an innovative stainless steel grade with $22 \% \mathrm{Cr}$ and a very low interstitial and stabilizing element content is here analyzed. Also Mo is kept at very low level in such materials with the aim to further lower their cost. Even if some data were already published on such materials mechanical behavior [27-31], not many data are still available on their corrosion resistance. Aim of this paper is to evaluate the corrosion resistance of 460LI steel aimed to face the materials selection criteria for stainless steels in specific applications.

\section{Experimental materials and methods}

AISI 460LI stainless steel is here considered in comparison to standard AISI 304 steel. The chemical composition of the analyzed steels is reported in Table 1 (in accordance to UNI EN 10088-2).

Table 1 Chemical composition of the analysed stainless steels (UNI EN 10088-2).

\begin{tabular}{|c|c|c|c|c|c|c|c|}
\hline & $\begin{array}{c}\mathrm{C} \\
(\%)\end{array}$ & $\begin{array}{c}\mathrm{N} \\
(\%)\end{array}$ & $\begin{array}{c}\mathrm{Cr} \\
(\%)\end{array}$ & $\begin{array}{c}\mathrm{Ni} \\
(\%)\end{array}$ & $\begin{array}{c}\mathrm{Ti} \\
(\%)\end{array}$ & $\begin{array}{c}\mathrm{Nb} \\
(\%)\end{array}$ & $\begin{array}{c}\text { Mo } \\
(\%)\end{array}$ \\
\hline $304(1.4301)$ & $\leq 0.07$ & $\leq 0.11$ & $17.5 \div 19.5$ & $8.0 \div 10.5$ & - & - & - \\
\hline 460LI (1.4611) & $<0.03$ & - & $19.0 \div 22.0$ & $<0.5$ & $<1$ & $<1$ & $<0.5$ \\
\hline
\end{tabular}


Materials corrosion resistance was assessed in terms of:

General corrosion resistance

General corrosion resistance has been tests in a salt spray chamber (WEISS system model SSC 450 ) at $35^{\circ} \mathrm{C}$ with a nebulized $5 \%$ wt of $\mathrm{NaCl}$ solution according to UNI EN ISO 9227. Samples were $100 \mathrm{~mm}$ x $200 \mathrm{~mm}$. Samples were cleaned with acetone before testing; edges were protected with wax and pix. Then, samples were placed into the chamber hunged on a plastic rack to maintain them at $20{ }^{\circ} \mathrm{C}$ respect to the vertical position. This arrangement was essential to avoid mutual contact between samples or with other parts of the chamber. Total duration of this test was $1000 \mathrm{~h}$. Generalized corrosion resistance from chemical agents and conditions typical for stainless steels was tested dipping samples of $20 \mathrm{~mm}$ x $50 \mathrm{~mm}$ dimensions (polished until to $120 \mathrm{mesh}$ ) in 8 solutions at different temperatures, as reported in Table 2 according to ASTM G157. Before the beginning of the test and after every exposure cycle, samples were weighted and measured to determine the corrosion rate expressed in $\mathrm{mm} /$ year.

Table 2 Tested stainless steels and solutions according to ASTM G157. (*only for 470LI)

\begin{tabular}{|c|c|}
\hline $\begin{array}{c}\text { Corrosive environment } \\
\text { (conc.\%) }\end{array}$ & $\begin{array}{c}\text { Test temperature } \\
\left.\text { ( }{ }^{\circ} \mathbf{C}\right)\end{array}$ \\
\hline Nitric acid (70\%) & 30,70 \\
\hline Acetic acid (80\%) & 30,70 \\
\hline Sodium chloride (50\%) & 30,70 \\
\hline Caustic soda (50\%) & $30,70,90,110 *$ \\
\hline Alum vitriol (10\%) & 30,70 \\
\hline Phosphoric acid (85\%) & 30,70 \\
\hline Methanol (99.9\%) & 30,70 \\
\hline Acetone (99.5\%) & 30,70 \\
\hline Urea (32.5\%) & $-5,45$ \\
\hline Orange juice (100\%) & 30 \\
\hline Milk (100\%) & 30,50 \\
\hline
\end{tabular}

\section{Localized corrosion resistance}

Potentio-dynamic polarization curves were measured using an electrochemical cell with three electrodes, with a calomel reference electrode (SCE) and a platinum counter-electrode, immersed in a $3 \% \mathrm{NaCl}$ solution at room temperature. To realize the potentio-dynamic curves, a Solatron 1287 was used connected to a PC for setting the beginning value of the potential scan, the power value and the surface $\left(1 \mathrm{~cm}^{2}\right)$ of metal exposed to the corrosive agent. Starting from a potential of $1 \mathrm{~V}$ (lower than the open circuit potential), a scan rate of $1 \mathrm{mV} / \mathrm{s}$ was set and an intensity of the inversion current equal to $5 \mathrm{~mA} / \mathrm{cm}^{2}$. Samples before the beginning of the test were polished until 600 mesh. Moreover:

Critical Pitting Temperature (CPT) has been determined by immersing different samples in a solution of $6 \% \mathrm{FeCl}_{3}$ for $24 \mathrm{~h}$ at a fixed temperature; this scheme was repeated increasing each time the solution's temperature of $5{ }^{\circ} \mathrm{C}$ until it was possible to observe the onset of pitting phenomena. Samples had dimensions of $30 \mathrm{~mm}$ x $40 \mathrm{~mm}$, with rounded corners. Moreover both samples' surfaces were polished at 120 mesh.

Crevice critical temperature (CCT) determination was realized with the same test procedure used to detect the critical pitting temperature (CPT). The only difference applied on the samples' surfaces regarded two Teflon cylinders with a diameter of $12 \mathrm{~mm}$. 20 embossed sectors were made 
on the cylinders and held together by a nickel-based alloy screw (shielded with Teflon). Test in salt spray chamber was performed applying on the samples two cylinders made in Teflon with a diameter of $50 \mathrm{~mm}$. On their surfaces were also obtained 12 embossed sector. Test duration was $260 \mathrm{~h}$ and the spray solution had a content of 5\% $\mathrm{NaCl}$ as reported in UNI EN ISO 9227. At the end of the cycle, samples were visually analyzed counting the number of sectors imprinted on the sample and assessing, with the same criteria, the gravity.

\section{Stress corrosion resistance}

Stress corrosion susceptibility was measured immerging samples, previously bended (U- bend samples), in a boiling solution of $\mathrm{MgCl}_{2}$ (42\%) for $500 \mathrm{~h}$, according to ASTM G30-97 standard. At the end of the test, samples were observed with a low magnification microscope, to identify the presence of cracks.

\section{Results}

Results of general corrosion resistance tests performed in corrosive environments for the 460LI steel are reported in Table 3. The testing environment has been chosen with the scope to put in evidence the material attitude to be put in service in applications including chemical sector and food industry. In every case, the result of the test was positive and the corrosion rate was widely within the ASTM G157 limit (0.13 mm/year).

Table 3 General corrosion resistance of 460LI for different corrosive media (ASTM G157). $\sqrt{\text { : }}$ corrosion rate $<0.13 \mathrm{~mm} /$ year; $\mathrm{X}$ : corrosion rate $>0.13 \mathrm{~mm} /$ year

\begin{tabular}{|c|c|c|c|c|}
\hline Steel & $\begin{array}{l}\text { Corrosive agent } \\
\text { (conc. \%) }\end{array}$ & $\begin{array}{l}\mathbf{T}_{\max } \\
\left({ }^{\circ} \mathbf{C}\right)\end{array}$ & Test result (48h) & Test result (96h) \\
\hline \multirow{10}{*}{ 460LI } & Nitric acid $(70 \%)$ & 70 & $\sqrt{ }$ & $\sqrt{ }$ \\
\hline & Acetic acid $(80 \%)$ & 70 & $\sqrt{ }$ & $\sqrt{ }$ \\
\hline & Sodium chlorate $(50 \%)$ & 70 & $\sqrt{ }$ & $\sqrt{ }$ \\
\hline & Caustic soda $(50 \%)$ & 70 & $\sqrt{ }$ & $\sqrt{ }$ \\
\hline & Alum vitriol (10\%) & 70 & $\sqrt{ }$ & $\sqrt{ }$ \\
\hline & Phosphoric acid (85\%) & 70 & $\sqrt{ }$ & $\sqrt{ }$ \\
\hline & Methanol $(99.9 \%)$ & 70 & $\sqrt{ }$ & $\sqrt{ }$ \\
\hline & Acetone $(99.5 \%)$ & 59 & $\sqrt{ }$ & $\sqrt{ }$ \\
\hline & Orange juice (100\%) & Boiling & $\sqrt{ }$ & $\sqrt{ }$ \\
\hline & Milk $(100 \%)$ & 50 & $\sqrt{ }$ & $\sqrt{ }$ \\
\hline
\end{tabular}

Passivation current density for AISI 460LI with respect to AISI 304 grade are reported in Table 4. Results show lower passivation current density with respect to standard AISI 304 steel. Such values are anyway typical of materials suitable for the target applications.

Table 4 Electrochemical parameters calculated in the anodic polarization curves in $3 \% \mathrm{NaCl}$ solution

\begin{tabular}{|c|c|c|c|}
\hline Steel & $\begin{array}{c}\mathbf{i}_{\text {pass }} \\
\left(\mathbf{A} / \mathbf{c m}^{2}\right)\end{array}$ & $\begin{array}{c}\mathbf{E}_{\text {pit }} \\
(\mathbf{m V / S C E})\end{array}$ & $\begin{array}{c}\mathbf{E}_{\text {rep }} \\
(\mathbf{m V} / \mathbf{S C E})\end{array}$ \\
\hline $460 \mathrm{LI}$ & $1.4 \cdot 10^{-6}$ & 430 & -110 \\
\hline 304 & $2.5 \cdot 10^{-6}$ & 360 & -66 \\
\hline
\end{tabular}


The critical pitting and crevice temperatures, calculated according to ASTM G48, are reported in Table 5. The critical pitting temperature of the super-ferritic stainless steel is higher than the austenitic stainless steel, while the pitting critical temperature is comparable.

Table 5 Comparison of CPT and CCT tested in a $10 \% \mathrm{FeCl}_{3}$ solution (ASTM G48-E and ASTM G48-F)

\begin{tabular}{|c|c|c|}
\hline Steel & $\mathbf{C P T}\left({ }^{\circ} \mathbf{C}\right)$ & CCT $\left({ }^{\circ} \mathbf{C}\right)$ \\
\hline 460 LI & 10 & 0 \\
\hline 304 & 4 & - \\
\hline
\end{tabular}

Photos of samples after crevice test in salt spray chamber for $260 \mathrm{~h}$ are reported in Fig. 1. The number of sectors imprinted on the sample and their severity are reported in Table 6. Results show similar behavior in the AIS 460LI and AISI 304 steels.

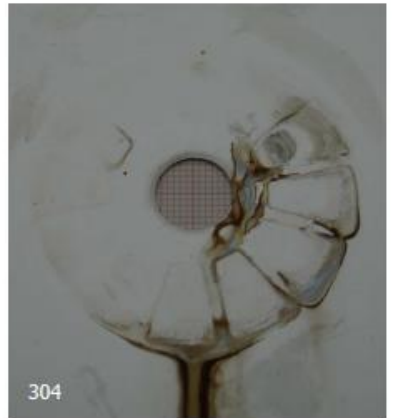

a)

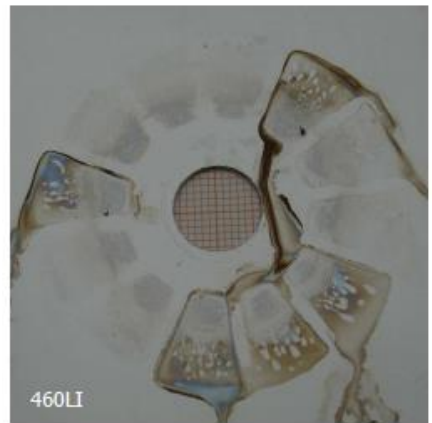

b)

Fig. 1 Samples tested in salt spray chamber for the crevice resistance test.

Table 6 Summary of visual inspection at the end of the salt spray chamber cycle.

\begin{tabular}{|c|c|c|}
\hline Steel & Embossed sector & Severity grade \\
\hline $460 \mathrm{LI}$ & 5 & Medium \\
\hline 304 & 5 & Medium \\
\hline
\end{tabular}

AISI 460LI and AISI 304 steel U-bend samples were immerged in a boiling solution of $\mathrm{MgCl} 2$ for $500 \mathrm{~h}$. At the end of the test, samples were observed with a low magnification microscope, to identify the presence of cracks and by Electron Scanning Microscope. Analyses reported that the super-ferritic samples are not susceptible to stress corrosion cracking while the tested samples of 304 achieves break, as expected for austenitic stainless steels.

\section{Conclusion}

The corrosion resistance of AISI 460LI super-ferritic stainless steel is analyzed.

Results show that:

AISI 460 LIA guarantee comparable properties with respectl of austenitic stainless steels in terms of general corrosion resistance. Also, the corrosion resistance tests through immersion in different environments detected low corrosion rates.

The pitting corrosion behavior was a little worst with respect to that of the AISI 304 steel grade. The super-ferritic stainless steels are not affected by stress corrosion. 


\section{References}

[1] P. Marshall: Austenitic stainless steels: Microstructure and Mechanical Properties, Elsevier Applied Science Publisher, 1984

[2] L. Viet, J. Hye-Jin: Metals, Vol.8, 2018, 815, https://doi.org/10.3390/met8100815

[3] C. Xingrun, R. Xiang: Metals, Vol. 8. 2018, 1024, https://doi.org/10.3390/met8121024

[4] D. Hongjinng: Metals, Vol. 9. 2019, 74, https://doi.org/10.3390/met9010074

[5] A. Tachieva: Metals, Vol. 9. 2019, 347, https://doi.org/10.3390/met9030347

[6] A. Prosviryakov: Metals, Vol. 9. 2019, 218, https://doi.org/10.3390/met9020218

[7] R. Rufini, O. Di Pietro, A. Di Schino: Metals, Vol. 8, 2018, 519, https://doi.org/10.3390/met8070519

[8] M. Corradi, A. Di Schino, A. Borri, R. Rufini: Constr. Build. Mater., Vol. 181, 2018, p. 335

[9] A. Borri, M. Corradi, G. Castrori, A. Molinari: Constr. Build. Mater. Vol. 211, 2019, p. 594, https://doi.org/10.1016/j.conbuildmat.2019.03.197

[10] C. Gennari, M. Lago, B. Bögre, I. Mezaros, I. Calliari, L. Pezzato: Metals. Vol. 8, 2018, 1074; https://doi.org/0.3390/met8121074

[11] A. Di Schino, M. Longobardo, G. Porcu. G. Turconi, L. Scoppio: NACE - International Conference Series 2006, 062151-06125114

[12] A. Di Schino, M. Barteri, J.M. Kenny: Journal of Materials Science Letters, Vol. 22, 2003, p. 1511, https://doi.org/10.1023/A:1026155215111

[13] A. Di Schino, J.M. Kenny, M. Barteri: Journal of Materials Science Letters, Vol. 22, 2003, p. 691, https://doi.org/0.1023/A:1023675212900

[14]A. Di Schino: Acta Metallurgica Slovaca, Vol. 22, 2016, p. 266, https://doi.org/10.12776/ams.v22i4.815

[15] M. Talha, C.K. Behera, O.P. Sinha: Mater. Sci. Eng. C, Vol. 33(7), 2013, p. 3563, https://doi.org/0.1016/j.msec.2013.06.002

[16]Boulané- Petermann, L., Biofouling, Vol. 10(4), 1996, p. 275

[17] G. Bregliozzi, S.I.U. Ahmed, A. Di Schino, K.M. Kenny, H. Haefke: Tribol. Lett., Vol. 17, 2004, p. 697, https://doi.org/10.1007/s11249-004-8075-z

[18] A. Di Schino, L. Valentini, J.M. Kenny, Y. Gerbig, I. Ahmed, H. Haefke: Surf. Coat. Technol., Vol. 161, 2002, p. 224, https://doi.org/10.1016/S0257-8972(02)00557-1

[19]A. Di Schino, J.M. Kenny, G. Abbruzzese: J. Mater. Sci., Vol. 37, 2002, p. 5291, https://doi.org/10.1023/A:1021068806598

[20] A. Di Schino, J.M. Kenny, I. Salvatori, G. Abbruzzese: J. Mater. Sci. , Vol. 36, 2001, p. 593, https://doi.org/10.1023/A:1004856001632

[21]L. Valentini, A. Di Schino, J.M. Kenny, Y. Gerbig, H. Haefke: Wear, Vol. 253, 2002, p.458, https://doi.org/10.1016/S0043-1648(02)00140-0

[22]C Zitelli, P. Folgarait, A. Di Schino: Metals, Vol. 9, 2019, 731, https://doi.org/10.3390/met9070731

[23]Z. Brytan, M.A. Grande, M. Rosso, R. Bidulský, L.A. Dobrzański: Materials Science Forum, Vol. 672, 2011, p. 165, https://doi.org/10.4028/www.scientific.net/MSF.672.165

[24]T. Kvačkaj, L.Sokolová, M. Vlado, V. Vrchovinský: High Temperature Materials and Processes, Vol. 24, 2005, Issue 2, p. 139, https://doi.org/10.1515/HTMP.2005.24.2.139

[25]L. Parilak, E. Dudrova, R. Bidulsky, M. Kabatova: Powder Technology, Vol. 322, 2017, p. 447, https://doi.org/10.1016/j.powtec.2017.09.027

[26]C. Wang, M. Wang, J. Shi, H. Dong, H: Scripta Materialia, Vol. 58, 2008, p. 492, D https://doi.org/10.1016/j.scriptamat.2007.10.053 
[27] S. Azuma, T. Kudo, H. Miyuki, M. Yamashita, H. Uchida: Corrosion Science, Vol. 46, 2004, p. 2265, https://doi.org/10.1016/j.corsci.2004.01.003

[28] J. N. Wanklyn: Corrosion Science, Vol. 21, 1981, p. 211, https://doi.org/10.1016/0010938X(81)90031-7

[29] Y. Peng Y: Metals, Vol. 9, 2019, 723, https://doi.org/10.3390/met9070723

[30]B. Atzori, P. Lazzarin, G. Meneghetti, M. Ricotta: Int. J. Fatigue, Vol. 31, 2009, p. 59, https://doi.org/10.1016/j.ijfatigue.2008.02.013

[31]R. De Finis, D. Palumbo, F. Ancona, U. Galietti: Int. J. Fatigue, Vol. 74, 2015, p. 88, https://doi.org/0.1016/j.ijfatigue.2014.12.010 